\section{Serological and molecular detection of Prune dwarf virus infecting stone fruits of Charmahal-va-Bakhtiari province, a central region of Iran}

\author{
Nourolah Soltani, ${ }^{1}$ Jamshid Hayati, \\ Ghobad Babaei, ${ }^{2}$ Maryam Ebrahim Qomi ${ }^{3}$ \\ 'Plant Protection Department, Faculty \\ of Agriculture, Shahid Chamran \\ University, Ahwaz; '2Plant Protection \\ Department, Chaharmahal-va-Bakhtiari \\ Research Center for Agriculture and \\ Natural Resources, Shahrekord; 'slamic \\ Azad University of Dezful, Iran
}

\begin{abstract}
Prune dwarf virus (PDV) is one of the major positive RNA viruses which cause economical damages in stone fruit trees. The symptoms of PDV vary between different stone fruits namely sour and sweet cherry, almond, peach, apricot and plum including leaf narrowing, leaf chlorosis, vein clearing, mosaic, leaf whitening, leathery leaf, bushy branches and stunt trees. During the years 2011 and 2012, 251 leaf samples were collected for detection of PDV in stone fruit orchards of Charmahal-vaBakhtiari province. DAS-ELISA test proved PDV presence serologically. Then, total RNA were extracted and tested by two-step RT-PCR which replicated partial and full coat protein sequence of PDV. One hundred and eighty one out of total samples (251 samples) showed PDV infection using serological and two-step RT-PCR assays, hence, incidence of PDV in Charmahal-va-Bakhtiari province was confirmed. This is the first report of PDV in stone fruit orchards of Charmahal-va-Bakhtiari province and in Iran.
\end{abstract}

\section{Introduction}

Viral diseases are one of the reducing factors of stone fruits yield, which RNA viruses play an important role in this loss. Charmahalva-Bakhtiari province has great areas under stone fruits cultivation in which viral diseases decrease production and fruits quality.

RNA viruses cause most of stone fruits economical damages. PDV whether solely or in mix infection causes loss of stone fruit products. ${ }^{1}$ The virus belongs to the Bromoviridae and $4^{\text {th }}$ subgroup of Ilarvirus, that has tripartite genome, single strand positive sense RNA and
5 ORFs. ORFs encode structural proteins, viral silencer suppressor, movement and capsid proteins. $^{2}$

PDV has no biological vector and cannot be transmitted by seed and pollen. Grafting infected scions and grafts is the main mood of its worldwide distribution. ${ }^{3,4}$ Cool nights and warm days increase symptoms development. ${ }^{5}$ PDV shows different symptoms in various stone fruits, stunting is observed in peach; yellows in sour cherry; stunting and leaf malformations in plums; and chlorotic spots, rings, and fruit rain cracking in sweet cherry. ${ }^{4,5}$ During various time periods of sample collection observed that at the end of growing season, viral concentration will be lowered, though, the symptoms are still visible. ${ }^{6}$ In mixed infections with Prunus necrotic ringspot virus (PNRSV) more damage will appear called stunting, but some of mixed infections with Apple mosaic virus (ApMV), Apple chlorotic leaf spot virus (ACLSV), American plum line pattern virus (APLPV) and Plum pox virus (PPV) has decreasing or no effect on PDV infection. ${ }^{7,8}$ Iran is the first producer of stone fruits and its derivatives in the world with 202,000 tones production. ${ }^{9}$

Charmahal-va-Bakhtiari province is one of the major producers of stone fruits namely almond and peach in the country with 19,300 and 12,600 tones productions, respectively. ${ }^{10}$

The objective of this research is investigating PDV on leaf samples of stone fruit orchards of Charmahal-va-Bakhtiari province by ELISA and PCR techniques.

\section{Materials and Methods}

\section{Sample collection}

During 2011 and 2012, 286 leaf samples of different stone fruit orchards of Charmahal-vaBakhtiari province were collected. Suspicious viral infected leaves were collected from four compass points of the trees with the symptoms as described in Table 1, and were carried on ice to lab.

\section{Mechanical transmission}

Curcubita maxima, Chenopodium album, Nicotiana tabacum var Turkish and $N$. rustica were inoculated by crude leaf homogenate of stone fruit leaves which were extracted in 0.1 M phosphate buffer, pH 7 containing 0.1\% 2mercaptoethanol. The homogenate was rubbed on the leaves coated with carborundum powder. The inoculated plants were kept under observation for two weeks to record potential symptoms.

\section{DAS-ELISA}

Serological test carried out by DAS-ELISA
Correspondence: Nourolah Soltani, Plant Protection Department, Agriculture Faculty, Shahid Chamran University, Ahwaz, Iran.

Tel. +98.913.402.2952.

E-mail: n85825@gmail.com

Key words: Prune dwarf virus, DAS-ELISA, twostep RT-PCR, Stone Fruits, Charmahal-vaBakhtiari province.

Contributions: the authors contributed equally.

Received for publication: 22 October 2012.

Revision received: 22 April 2013.

Accepted for publication: 5 June 2013.

This work is licensed under a Creative Commons Attribution NonCommercial 3.0 License (CC BYNC 3.0).

(C) Copyright N. Soltani et al., 2013

Licensee PAGEPress srl, Italy

International Journal of Plant Biology 2013; 4:e4 doi:10.4081/pb.2013.e4

using commercial polyclonal antibody of Prune dwarf virus (Bioreba, Switzerland) and with Clark and Adams method (1977). ELISA Plate was pre-coated with coating antibody that was diluted in coating buffer $\left(0.01 \mathrm{M} \mathrm{Na}_{2} \mathrm{CO}_{3}, 0.03\right.$ $\mathrm{M} \mathrm{NaHCO}_{3}, 3 \mathrm{mM} \mathrm{NaN}$ per L, pH 9.6) at 1:1000, and incubated overnight at $4^{\circ} \mathrm{C}$. The plate was washed with PBST buffer $(0.1 \mathrm{M}$ $\mathrm{NaCl}, 0.001 \mathrm{M} \mathrm{KH}_{2} \mathrm{PO}_{4}, 0.02 \mathrm{M} \mathrm{Na}_{2} \mathrm{HPO}_{4} .12 \mathrm{H}_{2} \mathrm{O}$, $0.002 \mathrm{M} \mathrm{KCl}, 0.003 \mathrm{M} \mathrm{NaN}_{3}, 0.5 \mathrm{~mL}$ Tween 20 per L, pH 7.4) three times, each time for $3 \mathrm{~min}$. $150 \mathrm{mg}$ of leaf samples were grounded by liquid nitrogen and mixed with $1 \mathrm{~mL}$ of extraction buffer [PBST+2\% Polyvniylpyrrolidone (PVP), $\mathrm{pH} 7.4$ ] and $200 \mathrm{~mL}$ of the homogenates were placed in wells. Plate was incubated at $4{ }^{\circ} \mathrm{C}$ overnight and washed five times with PBST buffer. Then Plate was coated with alkaline phosphatase conjugated antibody diluted in conjugate buffer (PBST, 2\% PVP, 0.2\% egg albumin, $\mathrm{pH}$ 7.4) at 1:1000, and incubated overnight at $37^{\circ} \mathrm{C}$. After washing, mixture of 4nitrophenyl phosphate diluted 1:1000 in substrate buffer ( $97 \mathrm{~mL}$ diethanolamine, $0.003 \mathrm{M}$ $\mathrm{NaN}_{3}, \mathrm{pH} 9.8$ ) was added to each well and incubated in a dark place at room temperature for 30-60 min. The reaction was detected at $\mathrm{OD}_{405 \mathrm{~nm}}$ using ELISA reader (STAT FAX 2100, USA).

\section{Total RNA extraction}

Total RNA of the both stone fruit leaves used as viral source of inoculation and inoculated indicator plants showed PDV infection, were isolated according to the $\mathrm{LiCl}$ method described by Channuntapipat et al. (2001) with some modifications. Approximately $100 \mathrm{mg}$ of infected leaves were grounded in liquid nitrogen and mixed with $1 \mathrm{ml}$ of extraction buffer 
(0.1 M LiCl, 0.1 M Tris-HCl, pH 8.0, $0.01 \mathrm{M}$ EDTA, pH 8.0, and 1\% SDS, PVP-40) 5\% w/v and sodium metabisulaphite $2 \% \mathrm{w} / \mathrm{v}) .800 \mu \mathrm{L}$ of a mixture of Tris-saturated phenol, $\mathrm{pH} 8.0$ : chloroform: isoamyl alcohol (25:24:1) were added to the tube and vortexed for $1 \mathrm{~min}$, followed by centrifugation at $14,000 \mathrm{rpm}$ for $15 \mathrm{~min}$ at room temperature (RT). The upper aqueous layer was transferred to a new tube and mixed with an equal volume of $4.0 \mathrm{M} \mathrm{LiCl}$. RNA was allowed to precipitate at $-20^{\circ} \mathrm{C}$ for $1-24 \mathrm{~h}$ to check the effect of freezing on RNA percipitation and its quality, which followed by centrifugation at $4^{\circ} \mathrm{C}$ for $15 \mathrm{~min}$ at $14,000 \mathrm{rpm}$. The pellet was dissolved in $400 \mu \mathrm{L}$ of sterile water and 2 volumes of cold $70 \%$ ethanol $\left(-20^{\circ} \mathrm{C}\right)$ in the presence of $40 \mu \mathrm{L}$ of $3.0 \mathrm{M} \mathrm{NaOAc}$ (pH 5.4). RNA was recovered by centrifugation at 14,000 rpm for $15 \mathrm{~min}$ at $4^{\circ} \mathrm{C}$. The pellet was washed
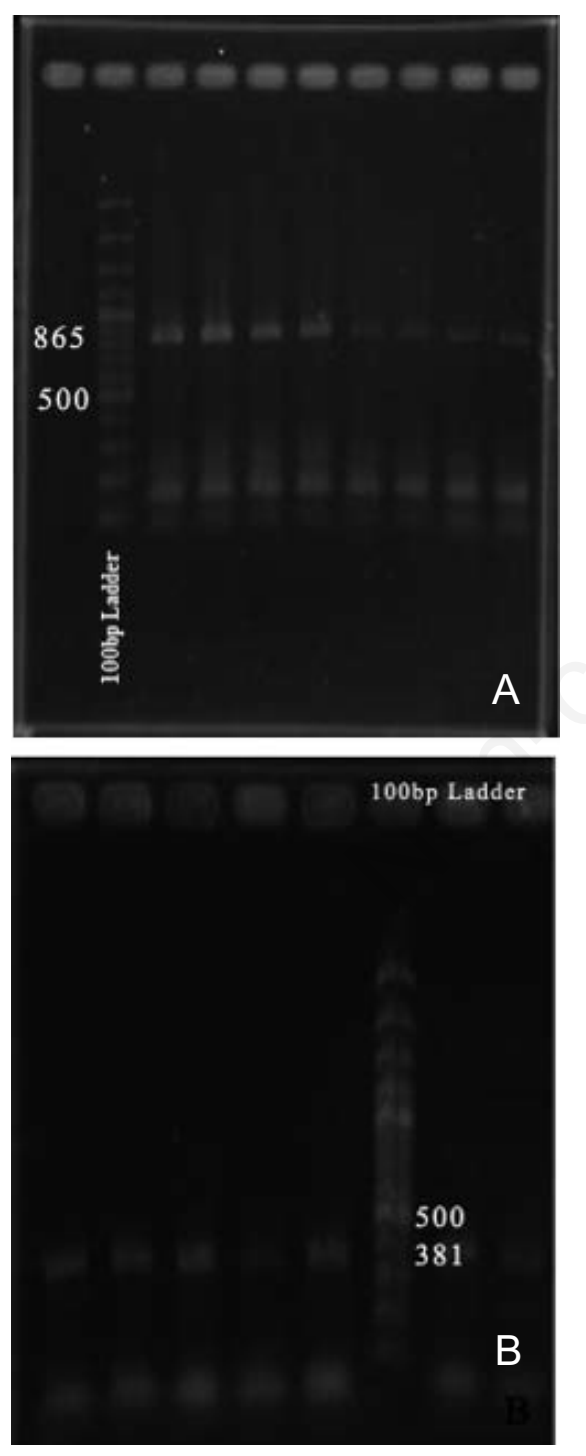

Figure 1. Amplified products with expected sizes. A) 865 bps amplified products, B) 381 bps amplified products. with $500 \mu \mathrm{L}$ cold $70 \%$ ethanol by centrifugation at $4000 \mathrm{rpm}$ for $5 \mathrm{~min}$ at $4^{\circ} \mathrm{C}$, dissolved in 40 $\mu \mathrm{L}$ of sterile water, and stored at $-20^{\circ} \mathrm{C}$ (or $-80^{\circ} \mathrm{C}$ for long-term storage). The quantity of RNA $\left(\mathrm{A}_{260 / 280}\right)$ was measured with Genova Spectrophotometer (Jenway, UK).

\section{Primers}

The conserved regions of PDV coat protein published on the GenBank database were aligned by using Mega5.1 (The Biodesign Institute, AZ, USA) software. Oligonucleotide primers were designed by Primer3 (Whitehead Institute for Biomedical Research, MA, USA) software with the results of aligned conserved regions. Choosing two pairs of primers for both partial and full sequence of PDV coat protein replication provided more accuracy and valid confirmation of molecular detection. The expected amplification products for partial and full sequence of PDV coat protein were $381 \mathrm{bps}$ and 865 bps, respectively (Table 2, Figure 1).

\section{cDNA synthesis and two-step RT- PCR}

Complementary DNA synthesis was carried out in $20 \mu \mathrm{L}$ total volume containing $5 \mu \mathrm{L}$ of extracted RNA, $1 \mu \mathrm{L}$ of random hexamer primer (100 pmole)(Genet Bio, Korea), $6 \mu \mathrm{L}$ of RNase-free water. This mixture was incubated for $10 \mathrm{~min}$ at $70^{\circ} \mathrm{C}$. Then $4 \mu \mathrm{L}$ of $5 \mathrm{X}$ reaction buffer $(250 \mathrm{mM}$ Tris-HCl pH 8.3, $250 \mathrm{mM} \mathrm{KCl}$, $20 \mathrm{mM} \mathrm{MgCl}_{2}, 50 \mathrm{mM}$ DTT), $2 \mu \mathrm{L}$ of dNTP mix $(10 \mathrm{mM})$, and $2 \mu \mathrm{L}$ of M-MuLV-Reverse transcriptase (40 units)(Genet Bio, Korea) were added. Reverse transcription was continued at $20-25^{\circ} \mathrm{C}$ for $10 \mathrm{~min}$ and followed by $42^{\circ} \mathrm{C}$ for 1 $\mathrm{h}$ and finally at $70^{\circ} \mathrm{C}$ for $10 \mathrm{~min}$. PCR mixture

Table 1. Natural host range of PDV and its symptoms.

\begin{tabular}{ll} 
Host & Viral symptoms in leaves \\
Prunus domestica & Yellowing, malformation, narrowing \\
\hline P. cerasus & Marginally whitening, wrinkling \\
P. armeniaca & Yellowing \\
\hline P. persica & Mosaic and yellowing \\
P. amygdalus & Mosaic, yellowing, malformation \\
& Mosaic, narrowing, malformation, leathery, \\
\hline
\end{tabular}

Table 2. Primers designed to detect PDV coat protein.

\begin{tabular}{lccc} 
Primers & \multicolumn{1}{c}{ Primer sequence } & Expected size & Primer length \\
PDV1F & 5- GGAAAGCCTACTGCCCGATCAC & & 22 \\
PDV1R & 5- CCTACGTTGTAGGGGATTAGG & 381 bps & 21 \\
PDV5F & 5-GAAGCTTTTGGTGTAACGATTGG & & 23 \\
PDV5R & 5-CAGTGACAAAATCTGAATGGTGG & 865 bps & 23 \\
\hline
\end{tabular}

Table 3. Mechanical transmission of PDV and its respective results.

\begin{tabular}{|c|c|c|c|c|c|}
\hline $\begin{array}{l}\text { Indicator } \\
\text { plants }\end{array}$ & $\begin{array}{c}\text { Inoculated } \\
\text { leaves as PDV } \\
\text { source }\end{array}$ & $\begin{array}{l}\text { Inoculated } \\
\text { indicator } \\
\text { plants }\end{array}$ & $\begin{array}{l}\text { Latent period } \\
\text { (days) }\end{array}$ & $\begin{array}{l}\text { Leaf growth } \\
\text { period }\end{array}$ & $\begin{array}{l}\text { Symptoms } \\
\text { in indicators }\end{array}$ \\
\hline $\begin{array}{l}\text { Cucumis } \\
\text { sativus }\end{array}$ & $\begin{array}{l}\text { Almond, sweet } \\
\text { and sour cherry, } \\
\text { plum, peach }\end{array}$ & 3 & 7 & Two leaves & $\begin{array}{l}\text { Mosaic, local } \\
\text { chlorosis in } \\
\text { margins and veins }\end{array}$ \\
\hline $\begin{array}{l}\text { Cucurbita } \\
\text { maxima }\end{array}$ & $\begin{array}{l}\text { Almond, sweet } \\
\text { and sour cherry, } \\
\text { plum, peach }\end{array}$ & 4 & 7 & Two leaves & $\begin{array}{l}\text { Mosaic, chlorosis } \\
\text { in margins and } \\
\text { veins }\end{array}$ \\
\hline $\begin{array}{l}\text { Nicotiana } \\
\text { tabacum } \\
\text { var Turkish }\end{array}$ & $\begin{array}{l}\text { Almond, sweet } \\
\text { cherry, sour cherry }\end{array}$ & 15 & 10 & $\begin{array}{l}\text { Two to four } \\
\text { leaves }\end{array}$ & Local chlorosis \\
\hline N. rustica & $\begin{array}{l}\text { Almond, sweet } \\
\text { cherry, sour cherry }\end{array}$ & 15 & 10 & $\begin{array}{l}\text { Two to four } \\
\text { leaves }\end{array}$ & $\begin{array}{l}\text { Local necrosis } \\
\text { and malformation }\end{array}$ \\
\hline $\begin{array}{l}\text { Chenopodium } \\
\text { album }\end{array}$ & $\begin{array}{l}\text { Almond, sweet } \\
\text { cherry, sour cherry }\end{array}$ & 6 & $7-10$ & $\begin{array}{l}\text { Four to six } \\
\text { leaves }\end{array}$ & Local chlorosis \\
\hline
\end{tabular}


in $20 \mu \mathrm{L}$ total volume containing $1 \mu \mathrm{L}$ of the cDNA, $0.8 \mu \mathrm{L}$ of $\mathrm{MgCl}_{2}(50 \mathrm{mM}), 0.6 \mu \mathrm{L}$ of dNTPs $(10 \mathrm{mM}), 1 \mu \mathrm{L}$ of each forward and reverse primer (10 pmole each), $2 \mu \mathrm{L}$ of $10 \mathrm{X}$ PCR reaction buffer (Genet Bio, Korea), 0.25 $\mu \mathrm{L}$ of Taq-polymerase ( $5 \mathrm{U}$ per $\mu \mathrm{L}$ ), and 13.4 $\mu \mathrm{L}$ of water were added. The cycling parameters for PDV5 primer were as follows: initial denaturation of $2 \mathrm{~min}$ at $94^{\circ} \mathrm{C}$ followed by 35 cycles of $30 \mathrm{sec}$ at $94^{\circ} \mathrm{C}, 40 \mathrm{sec}$ at $45^{\circ} \mathrm{C}, 1 \mathrm{~min}$ at $72^{\circ} \mathrm{C}$ and final extension to $5 \mathrm{~min}$ at $72^{\circ} \mathrm{C}$. All the parameters for PDV1 primer is the same as PDV5 except annealing temperature which changed to $50^{\circ} \mathrm{C}$. The amplification products were analyzed using electrophoresis through $1.5 \%$ agarose gels in $1 \times$ TBE buffer $(\mathrm{pH} 8.0)$ at a current of 30-40 mA. After electrophoresis, gels were stained with ethidium bromide ( 0.5 $\mathrm{g} / \mathrm{mL}$ ), and visualised under UV light.

\section{Results}

\section{Mechanical transmission}

Inoculation of indicator plants with homogenate of infected stone fruit leaves showed different symptoms on different hosts as illustrated in Figure 2. Cucurbita maxima showed mosaic, vein yellowing and chlorosis; symptoms of Chenopodium album were in range of local chlorosis and the predominant symptoms of both Nicotiana species were local chlorosis and local necrosis. The stone fruits used as PDV source were successfully transmitted to indicator plants during their 2 to 6 leaves. Latent period of virus varied about 7-10 days among different indicator plants. Complementary information about PDV transmission is described in Table 3 .

\section{DAS-ELISA}

The results of 251 tested samples revealed $72.1 \%$ positive infection to PDV. Measuring OD405 nm provided information of PDV titre in tested stone fruit hosts. One of the almond leaf samples had OD about 1.5, which in comparison with PDV positive control with OD 1.6 was remarkable. After almond samples sweet cherry and peach had the most PDV titre in their leaf samples (Table 4).

\section{RNA extraction and two-step RT- PCR}

The range of extracted total RNA of both stone fruit leaves used as viral source of inoculation and inoculated indicator plants showed PDV infection in $\mathrm{A}_{260 / 280}$ was 1.8. The fragments with partial and full sequence of coat protein, respectively, 381 and 865 bps were amplified. Therefore, presence of PDV was confirmed with designed primers in both host and indicator plants. Instead of using negative controls, utilizing two pairs of primers was only for confident of PDV presence in leaf samples which may be mistaken with unwanted amplified plant genes.

\section{Discussion}

As symptoms of viral infection retained in leaves, at the end of the growth season and by increasing temperature, viral concentration decreases. As reported, In this situation peri- carp (fruit skin) is preferable compared to leaf and other plant tissues. ${ }^{6}$ Reaching to a definite result needs to know accurate time of sampling which help to collect infected leaves with high viral concentrations. Symptomology studies on Charmahal-va-Bakhtiari stone fruits samples showed diverse and wide range of symptoms including mosaic, yellowing, malformation, narrowing, whitening, bushy branches and stunt tree.

Both the $C$. maxima and $C$. sativus as indicator plants were more sensitive to PDV than other three indicators because of viral latent

Table 4. Infection percentage of PDV on various collected samples of stone fruits.

\begin{tabular}{lcccc}
$\begin{array}{l}\text { Stone } \\
\text { fruits }\end{array}$ & $\begin{array}{c}\text { Total n. of } \\
\text { collected samples }\end{array}$ & $\begin{array}{c}\text { Total } \mathbf{n} \text {. infected } \\
\text { samples }\end{array}$ & $\begin{array}{c}\text { Infection } \\
\text { percentage }\end{array}$ & Most $^{\text {0 D }} \mathbf{4 0 5 \mathrm { mm }}$ \\
Almond & 182 & 126 & 69.2 & 1.5 \\
Apricot & 6 & 3 & 50 & 0.145 \\
\hline Sweet cherry & 19 & 19 & 100 & 1.01 \\
Sour cherry & 6 & 6 & 100 & 0.35 \\
\hline Peach & 16 & 13 & 81.2 & 0.67 \\
Plum & 22 & 14 & 63.6 & 0.455 \\
\hline Total & 251 & 181 & 72.1 &
\end{tabular}

Positive control $=1.6$
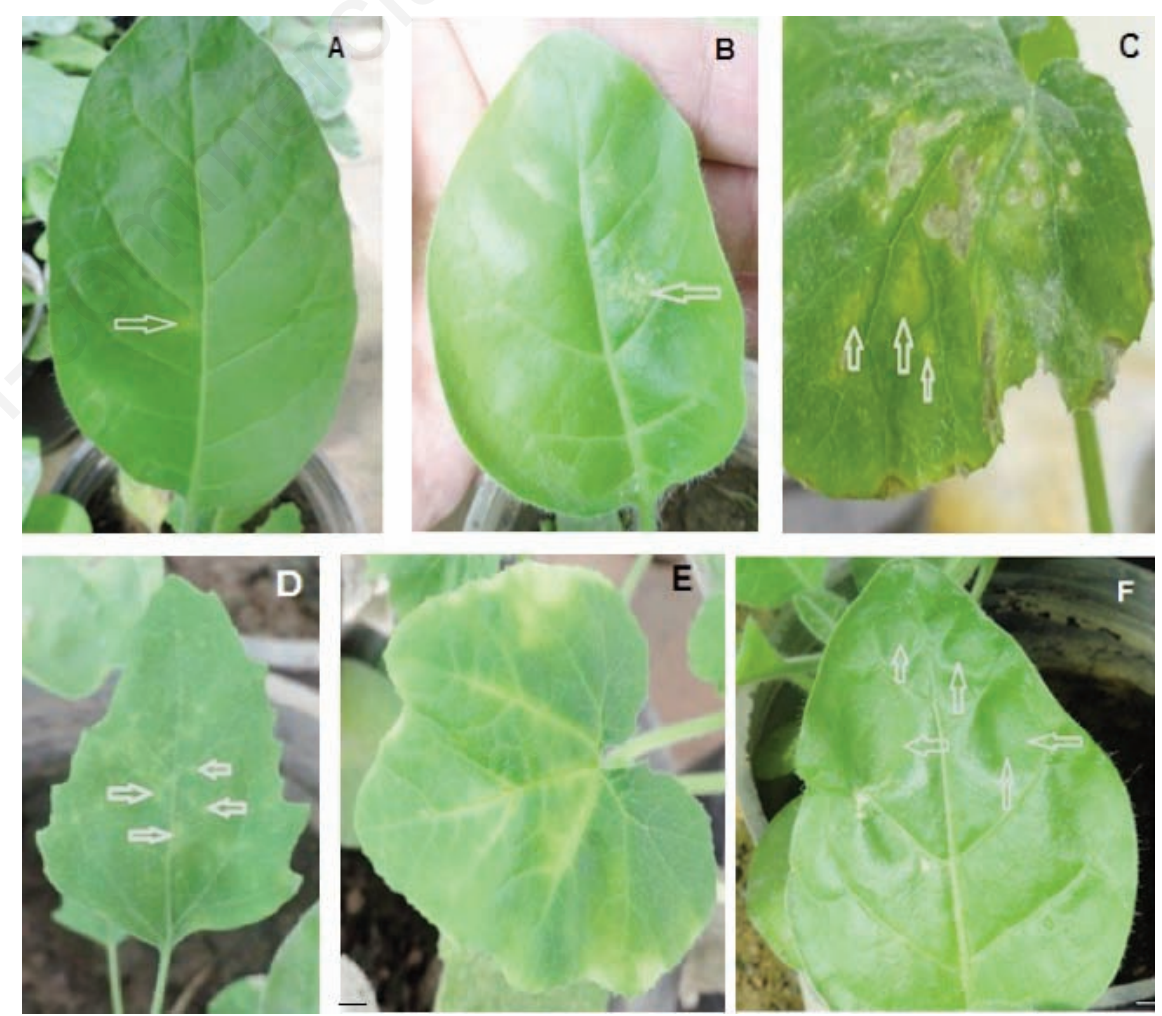

Figure 2. Different symtoms of PDV inoculation to indicator plants. A) Local chlorosis (Arrow) on N. tabacum var.Turkish, B) Local necrosis (Arrow) on N. rustica, C) Mosaic, local chlorosis (Arrows) on C. sativus, D) Local chlorosis (Arrows) on C. album. E) Mosaic, chlorosis and vein yellowing (Arrows) on C. maxima. F) Leaf malformation (Arrows) on N. rustica. 
period and symptoms development on leaf surface. Although, some factors like uneven distribution, leaf age differences and seasonal fluctuation make ELISA as an inaccurate and inefficient method but this is the most routine approach for viral detection. ${ }^{7}$ To confirm the results of DAS-ELISA, two-step RT-PCR with specific coat protein primers was carried out.

Serological and molecular results indicate that high incidence of PDV (72.1\%) has been taken place among stone fruits of the province. According to viral concentration in leaf tissue, among mentioned stone fruits in Charmahalva-Bakhtiari province almond, sweet cherry and peach had the most PDV infection and plum, sour cherry and apricot have little infection to PDV. Although, sour cherry has $100 \%$ infection in our results of experiments but in serological and molecular methods revealed little virus titre (Table 4).

Since no natural vectors for spreading this virus have been described, and mechanical transmission is the main factor of transmission, the production of virus-free reproductive and planting material and its usage for the establishment of new plantings are important for effective virus control. However, the eradication of infected mother plants is a significant part of the certification system of nursery material in Charmahal-va-Bakhtiari province.

Studying about genetic diversity of PDV coat protein in stone fruits of Charmahal-vaBakhtiari province or a broader area, in Iran, not only extends probably iranian isolate of PDV genome library but also would help in future controlling methods of this virus.

Both of these items could be the next field of study.

\section{References}

1. ICTVdb Virus Description. Prune dwarf virus. 2006. Available form: http://ictvdb.bio-mirror.cn/ICTVdB/00. 010.0.02.014.html.

2. Brunt AA, Crabtree K, Dallwitz MJ, et al. Viruses of plants. London: CAB International; 1996. pp 1044-1046.

3. Fonseca F, Net JD, Martins V, Nolasco G. Genomic variability of prune dwarf virus as affected by agricultural practice. Arch Virol 2005;150:1607-19.

4. Kelly RD, Cameron HR. Location of Prune dwarf and Prunus necrotic ringspot viruses associated with sweet cherry pollen and seed. Phytopathol 1986;76:317-22.

5. Jarosova J, Kundu JK. Detection of Prune dwarf virus by one-step RT-PCR and its quantitation by real-time PCR. J Vir Meth 2010;164:139-44.

6. Uyemoto JK, Asai WK, Luhn CK. Ilarviruses: evidence for rapid spread and effects on vegetative growth and fruit yields of peach trees. Plant Dis 1992;76:71-4.

7. Matic S, Sanchez-Navarro JA, Mandic B, et al. Tracking three Ilarviruses in stone fruit tress throughout the year by ELISA and tissue-printing hybridization. J Plant Path 2008;90:137-41.

8. Polak J, Ravelonandro M, Kumar-kundu J, et al. Interactions of Plum pox virus strain Rec with Apple chlorotic leafspot virus and Prune dwarf virus in field-grown transgenic plum Prunus domestica L., clone C5. Plant Protec Sci 2008;44:1-5.

9. Faostat. 2011. Available from: http://faostat.fao.org.

10. Charmahal-va-Bakhtiari province agricultural organization. 2011. Available from: http://chb-agri-jahad.ir/chb.

11. Channuntapipat C, Sedgley M, Collins G. Sequences of the cDNAs and genomic DNAs encoding the S1, S7, S8, and Sf alleles from almond, Prunus dulcis. Theor Appl Genet 2001;103:1115-22.

12. Codoner MF, Elena SF. The promiscuous evolutionary history of the family Bromoviridae. J Gen Virol 2008;89:173947.

13. Guo D, Maiss E, Adam G, Casper R. Prunus necrotic ringspot ilarvirus: nucleotide sequence of RNA3 and the relationship to other ilarviruses based on coat protein comparison. J Gen Virol 1995;76:1073-9.

14. Jaspars EMJ. Genome activation in alfamo- and ilarviruses. Arch Virol 1999;144:843-63.

15. Mekuria G, Ramesh SA, Alberts E, et al. Comparison of ELISA and RT-PCR for the detection of PNRSV and PDV in Australian almond trees. Options Mediterraneennes 2003:193-6.

16. Mekuria G, Ramesh SA, Alberts E, et al. Comparison of ELISA and RT-PCR for the detection of Prunus necrotic ring spot virus and Prune dwarf virus in almond (Prunus dulcis). J Vir Meth 2003;114:65-9.

17. Rowhani A, Maningas MA, Lile LS, et al. Development of a detection system for viruses of woody plants based on PCR analysis of immobilized virions. Phyto pathol 1995;85:347-52.

18. Saade M, Aparicio F, Sanchez-Navarro JA, et al. Simultaneous detection of the three Ilarviruses affecting stone fruit trees by non-isotopic molecular hybridization and multiplex reverse-transcription polymerase chain reaction. Phytopathol 2000:1330-6.

19. Untiveros M, Perez-Egusquiza Z, Clover G. PCR assays for the detection of members of the genus Ilarvirus and family Bromoviridae. J Vir Meth. 2010;165:97104.

20. Usta M, Sipahioglu HM, Polat B. Comparison of DAS-ELISA and RT-PCR methods for the detection of Prunus necrotic ringspot virus (PNRSV). J Agri Sci 2005;15:153-8. 